\title{
FAKTOR-FAKTOR YANG BERHUBUNGAN DENGAN TINGKAT KECEMASAN PADA PASIEN PREOPERATIVE DI RS MITRA HUSADA PRINGSEWU
}

\author{
Diny Vellyana ${ }^{1}$, Arena Lestari ${ }^{2}$, Asri Rahmawati ${ }^{3}$ \\ ${ }_{1,2,3}$ STIKes Muhammadiyah Pringsewu Lampung \\ Email: dinyvellyana@yahoo.com
}

\begin{abstract}
Related Factors with Anxiety Level of Preoperative Patient in Mitra Husada Hospital, Pringsewu. All of the nursing intervention in hospital was not certainly be positively accepted by patients. People ability has different, so that can arise the stress condition or anxiety. The prevalence of anxiety in America were more than 28\%. The age who get anxiety were 9-17 years, $13 \%$ age of $18-54$ years, $16 \%$ age of 55 and $11.4 \%$ of elderly. Women have risk to anxiety, two times than man. This study was to know the factors that related to anxiety level in Preoperative patient in Mitra Husada Hospital, Pringsewu, in 2016. The method of this study was a correlation with using cross sectional approach. The population were 58 respondents. Technique of sampling was using accidental sampling. Data were analyzed by univariat and bivariat using Chi square. The result showed that there were a relationship of gender, age, and economic status (pvalue $<0.05$ ) and there were not a relationship of level of education variable ( $p$-value $>0.05$ ) with the anxiety level of Preoperative patient in Mitra Husada Hospital, Pringsewu.
\end{abstract}

Keywords: Anxiety, Preoperative

\begin{abstract}
Abstrak: Faktor-Faktor yang Berhubungan dengan Tingkat Kecemasan pada Pasien Preoperative di RS Mitra Husada Pringsewu. Semua tindakan perawatan di rumah sakit dengan segala macam tindakan belum tentu dapat diterima secara positif oleh semua pasien. Kemampuan adaptasi seseorang berbeda beda, sehingga bisa muncul kondisi stres atau kecemasan. Angka kejadian kecemasan di Amerika 28\% atau lebih. Usia yang mengalami kecemasan 9-17 tahun. $13 \%$ usia 18-54 tahun, $16 \%$ usia 55 dan lansia 11,4\%. Jenis kelamin wanita 2 kali lebih banyak beresiko mengalami kecemasan dibandingkan laki laki. Tujuan Penelitian ini adalah untuk mengetahui faktor-faktor yang mempengaruhi tingkat kecemasan pasien pre operative di RS Mitra Husada Pringsewu Lampung Tahun 2016. MetodePenelitian ini merupakan penelitian korelasi dengan menggunakan pendekatan cross sectional. Populasi dalam penelitian ini adalah seluruh pasien Preoperative sebanyak 58 responden. Teknik pengambilan sampel dalam penelitian ini menggunakan metode accidental sampling. Analisis data univariat dan bivariatnya menggunakan uji statistic Chi Square. Hasilpenelitian menunjukkan bahwa ada hubungan antara jenis kelamin, usia dan status ekonomi dengan tingkat kecemasan pasien Preoperative di RS Mitra Husada Pringsewu dengan $p$-value $<0,05$ namun pada variabel tingkat pendidikan tidak terdapat hubungan dengan tingkat kecemasan $p$-value $>0,05$. Implikasi dari penelitian ini diharapkan perawat dapat memberikan treatment relaksasi untuk menurunkan kecemasan pada pasien Preoperative yang mengalami kecemasan supaya persiapan preoperasi dapat berjalan dengan baik.
\end{abstract}

Kata kunci: Kecemasan, Preoperative

Semua tindakan perawatan di rumah sakit dengan segala macam tindakan belum tentu dapat diterima secara positif oleh semua pasien. Setiap keadaan atau peristiwa yang menimbulkan perubahan dalam kehidupan seseorang, menuntut individu tersebut harus menyesuaikan diri untuk mengatasinya, maka perlu adanya adaptasi, tetapi kemampuan adaptasi seseoarang berbeda-beda, sehingga bisa muncul kondisi stres atau kecemasan (Hawari, 2013).

Kecemasan merupakan kondisi emosional yang ditandai dengan kekhawatiran yang berlebihan terhadap berbagai peristiwa kehidupan sehari hari. Kecemasan yang dirasaka sulit dikendalikan dan berhubungan dengan gejala somatic, seperti ketegangan otot, iritabilitas, kesulitan tidur dan kegelisahan (Utama, 2013).

Aspek penting emosi adalah efeknya pada selektifitas perhatian. Orang yang mengalami kecemasan cenderung memperhatikan hal tertentu di dalam lingkunganya dan mengabaikan hal lain dalam upaya membuktikan bahwa mereka dibenarkan untuk menganggap situasi itu menakutkan. Jika keliru dalam membenarkan 
rasa takutnya,mereka akan meningkatkan kecemasan dengan respon yang selektif, persepsi yang distorsi (Kaplan \& Saddock, 2010).

Angka kejadian kecemasan di Amerika $28 \%$ atau lebih. Usia yang mengalami kecemasan 9-17 tahun. $13 \%$ usia $18-54$ tahun, $16 \%$ usia 55 dan lansia $11,4 \%$. Jenis kelamin wanita 2 kali lebih banyak beresiko mengalami kecemasan dibandingkan laki laki (Fortinesh, 2007).

Berdasarkan hasil pra-survey di Ruang Rawat Inap Bedah Rumah Sakit Mitra Husada Pringsewu pada bulan Februari 2016 didapatkan hasil dari wawancara pada 10 pasien dengan Preoperative sebanyak 8 (delapan) pasien dengan jenis tindakan operasi mayor mengatakan mengalami kekhawatiran dalam menghadapi operasi, hal tersebut dikuatkan dengan pernyataan pasien yang mengatakan tidurnya sering terbangun dan sulit tidur. Sedangkan 2 (dua) pasien mengatakan tidak terlalu takut karena sudah pasrah. Klasifikasi usia 8 orang dewasa dan 2 lansia, jenis kelamin wanita sebanyak 6 dan 4 pasien laki laki (Data Primer RS Mitra Husada, 2016).

Berdasarkan latar belakang diatas rumusan masalah pada penelitian ini adalah Apakah ada hubungan antara usia, jenis kelamin, pendidikan, dan status ekonomi dengan tingkat kecemasan pasien preoperative di ruang rawat inap Rumah Sakit Mitra Husada Pringsewu tahun 2016.

\section{METODE PENELITIAN}

Jenis penelitian ini yaitu korelasi dengan pendekatan yang digunakan pada penelitian ini adalah cross sectional. Peneliti menekankan waktu pengukuran atau observasi data variabel independen dan dependen hanya satu kali pada satu saat, yaitu untuk menggambarkan faktorfaktor yang berhubungan dengan tingkat kecemasan pasien yang akan menghadapi operasi mayor.

Variabel penelitian ini ada dua yaitu independen yaitu variabel yang menjadi sebab timbulnya atau berubahnya variabel dependen, yang terdiri dari usia, jenis kelamin, pendidikan dan status ekonomi (Sugiyono, 2007), dan variabel dependen yaitu variabel yang dipengaruhi atau yang menjadi akibat karena adanya variabel bebas yang terdiri dari tingkat kecemasan.

\section{HASIL}

\section{A. Hubungan Tingkat Pendidikan dengan Tingkat Kecemasan}

Tabel 1. Distribusi Hubungan Tingkat Pendidikan dengan Tingkat Kecemasan

\begin{tabular}{|c|c|c|c|c|c|c|c|c|c|c|c|}
\hline \multirow{3}{*}{ Pendidikan } & \multicolumn{11}{|c|}{ Tingkat Kecemasan } \\
\hline & \multicolumn{2}{|c|}{$\begin{array}{l}\text { Tidak } \\
\text { Cemas }\end{array}$} & \multicolumn{2}{|c|}{$\begin{array}{l}\text { Cemas } \\
\text { Ringan }\end{array}$} & \multicolumn{2}{|c|}{$\begin{array}{l}\text { Cemas } \\
\text { Sedang }\end{array}$} & \multicolumn{2}{|c|}{$\begin{array}{l}\text { Cemas } \\
\text { Berat }\end{array}$} & \multicolumn{2}{|c|}{ Total } & \multirow[t]{2}{*}{ p-value } \\
\hline & $\mathbf{n}$ & $\%$ & $\mathbf{n}$ & $\%$ & $\mathbf{n}$ & $\%$ & $\mathbf{n}$ & $\%$ & $\mathbf{n}$ & $\%$ & \\
\hline SD & 5 & 17.9 & 14 & 50 & 9 & 32.1 & 0 & 0 & 28 & 100 & \\
\hline SMP & 1 & 2.5 & 4 & 50 & 3 & 37.5 & 0 & 0 & 8 & 100 & 0.643 \\
\hline SMA & 3 & 14.3 & 11 & 52.4 & 6 & 28.6 & 1 & 4.8 & 21 & 100 & \\
\hline Sarjana & 1 & 100 & 0 & 0 & 0 & 0 & 0 & 0 & 1 & 100 & \\
\hline Total & 10 & & 9 & & 18 & & 1 & & 58 & & \\
\hline
\end{tabular}

Berdasarkan tabel 1 di atas hasil analisis hubungan tingkat pendidikan dengan tingkat kecemasan didapatkan bahwa dari 10 responden yang tidak mengalami kecemasan 5 (17.9\%) respondennya adalah dari pendidikan $\mathrm{SD}, 1$ (2.5\%) yaitu pendidkan SMP, 3 (14.3\%) dan 1(100) dari pendidikan Sarjana. Sebanyak 14 (50\%) responden dengan pendidikan SMP mengalami cemas ringan, $11(52.4 \%)$ responden pendidikan SMA dan 0 responden untuk pendidikan sarjana. Untuk tingkatan kecemasan sedang yang terbanyak yaitu pendidikan SD 9 $(32,1 \%)$ responden, diikuti pendidikan SMA sebanyak 6 (28.6\%) dan 3 (37.5\%). Sedangkan tingkat kecemasan yang berat adalah $1(4.8 \%)$ hanya pada pendidikan SMA dan $0(0 \%)$ pada semua pendidikan SD, SMP dan Sarjana. Hasil $p$ value menunjukkan $0.643>0.05$ yang berarti bahwa tidak ada hubungan antara pendidikan dengan tingkat kecemasan. 


\section{B. Hubungan Usia dengan Tingkat Kecemasan}

Tabel 2. Distribusi Hubungan Usia dengan Tingkat Kecemasan

\begin{tabular}{|c|c|c|c|c|c|c|c|c|c|c|c|}
\hline \multirow{3}{*}{ Usia } & \multicolumn{11}{|c|}{ Tingkat Kecemasan } \\
\hline & \multicolumn{2}{|c|}{$\begin{array}{c}\text { Tidak } \\
\text { Cemas }\end{array}$} & \multicolumn{2}{|c|}{$\begin{array}{l}\text { Cemas } \\
\text { Ringan } \\
\end{array}$} & \multicolumn{2}{|c|}{$\begin{array}{c}\text { Cemas } \\
\text { Sedang } \\
\end{array}$} & \multicolumn{2}{|c|}{$\begin{array}{c}\text { Cemas } \\
\text { Berat } \\
\end{array}$} & \multicolumn{2}{|c|}{ Total } & \multirow[t]{2}{*}{ p-value } \\
\hline & $\mathbf{n}$ & $\%$ & $\mathbf{n}$ & $\%$ & $\mathbf{n}$ & $\%$ & $\mathbf{n}$ & $\%$ & $\mathbf{n}$ & $\%$ & \\
\hline Remaja & 1 & 3.6 & 16 & 57.1 & 11 & 9.3 & 0 & 0 & 28 & 100 & 0.036 \\
\hline Dewasa & 9 & 30 & 13 & 43.3 & 7 & 3.3 & 1 & 3.3 & 8 & 100 & \\
\hline Total & 10 & & 29 & & 18 & & 1 & & 58 & & \\
\hline
\end{tabular}

Berdasarkan tabel 2 di atas hasil analisis hubungan usia dengan tingkat kecemasan didapatkan sebanyak $9(30 \%)$ usia dewasa tidak cemas dan hanya $1(3.6 \%)$ pada usia remaja. Usia Remaja dengan kecemasan ringan sebanyak 16 $(57.1 \%)$ dan $13(43 \%)$ pada usia dewasa, tingkat kecemasan sedang sebanyak 11 (39.3\%) pada usia remaja dan hanya 7 (23.3\%) pada usia dewasa. Untuk tingkat kecemasan berat hanya ditemukan pada responden usia dewasa yaitu 1 (3.3\%). Hasil p-value $0.036<0.05$ yang berarti bahwa terdapat hubungan yang signifikan antara usia dengan tingkat kecemasan.

\section{Hubungan Jenis Kelamin dengan Tingkat kecemasan}

Tabel 3. Distribusi Hubungan Jenis Kelamin dengan Tingkat Kecemasan

\begin{tabular}{|c|c|c|c|c|c|c|c|c|c|c|c|}
\hline \multirow{3}{*}{$\begin{array}{c}\text { Jenis } \\
\text { Kelamin }\end{array}$} & \multicolumn{11}{|c|}{ Tingkat Kecemasan } \\
\hline & \multicolumn{2}{|c|}{$\begin{array}{c}\text { Tidak } \\
\text { Cemas }\end{array}$} & \multicolumn{2}{|c|}{$\begin{array}{l}\text { Cemas } \\
\text { Ringan }\end{array}$} & \multicolumn{2}{|c|}{$\begin{array}{l}\text { Cemas } \\
\text { Sedang }\end{array}$} & \multicolumn{2}{|c|}{$\begin{array}{c}\text { Cemas } \\
\text { Berat }\end{array}$} & \multicolumn{2}{|c|}{ Total } & \multirow[t]{2}{*}{$p$-value } \\
\hline & $\mathbf{n}$ & $\%$ & $\mathbf{n}$ & $\%$ & $\mathbf{n}$ & $\%$ & $\mathbf{n}$ & $\%$ & $\mathbf{n}$ & $\%$ & \\
\hline Laki - laki & 5 & 23.8 & 14 & 66.7 & 2 & 9.5 & 0 & 0 & 21 & 100 & 0.043 \\
\hline Perempuan & 5 & 13.5 & 15 & 40.5 & 16 & 43.2 & 1 & 2.7 & 37 & 100 & \\
\hline Total & 10 & & 29 & & 18 & & 1 & & 58 & & \\
\hline
\end{tabular}

Berdasarkan tabel 3 di atas hasil analisis hubungan jenis kelamin dengan tingkat kecemasan pasien dihasilkan bahwa 1 (2.7\%) responden dengan jenis kelamin perempuan memiliki tingkat kecemasan berat, $16(43.2 \%)$ memiliki kecemasan sedang, $15 \quad(40.5 \%)$ memiliki kecemasan ringan dan yang tidak cemas hanya $5(13.5 \%)$. Hal tersebut berbeda dengan tingkat kecemasan pasien dengan jenis kelamin laki-laki yaitu cemas sedang sebanyak $2(9.5 \%)$, cemas ringan ada $14(66.7 \%)$, dan tidak cemas hanya $5(23.8 \%)$. Hasil p-value menunjukkan $0.043<0.05$ yang berarti bahwa terdapat hubungan antara jenis kelamin dengan tingkat kecemasan pasien preoperative.

\section{Hubungan Status Ekonomi dengan Tingkat Kecemasan}

Tabel 4. Distribusi Hubungan Status Ekonomi dengan Tingkat Kecemasan

\begin{tabular}{|c|c|c|c|c|c|c|c|c|c|c|c|}
\hline \multirow{3}{*}{ Penghasilan } & \multicolumn{11}{|c|}{ Tingkat Kecemasan } \\
\hline & \multicolumn{2}{|c|}{$\begin{array}{l}\text { Tidak } \\
\text { Cemas }\end{array}$} & \multicolumn{2}{|c|}{$\begin{array}{l}\text { Cemas } \\
\text { Ringan }\end{array}$} & \multicolumn{2}{|c|}{$\begin{array}{l}\text { Cemas } \\
\text { Sedang }\end{array}$} & \multicolumn{2}{|c|}{$\begin{array}{l}\text { Cemas } \\
\text { Berat }\end{array}$} & \multicolumn{2}{|c|}{ Total } & \multirow[t]{2}{*}{$p$-value } \\
\hline & n & $\%$ & $\mathbf{n}$ & $\%$ & $\mathbf{n}$ & $\%$ & n & $\%$ & $\mathbf{n}$ & $\%$ & \\
\hline Dibawah UMR & 2 & 5.7 & 21 & 60 & 12 & 34.3 & 0 & 0 & 21 & 100 & 0.016 \\
\hline Diatas UMR & 8 & 4.8 & 8 & 4.8 & 6 & 26.1 & 1 & 4.3 & 37 & 100 & \\
\hline Total & 10 & & 29 & & 18 & & 1 & & 58 & & \\
\hline
\end{tabular}

Tabel di atas menjelaskan bahwa dari hasil penelitian menunjukkan $21(60 \%)$ responden dengan penghasilan dibawah UMR mengalami kecemasan ringan. $12(34.3 \%)$ mengalami cemas sedang dan $2(5.7 \%)$ responden tidak cemas. Sedangkan pada jumlah penghasilan diatas UMR yaitu terdapat $1(4.3 \%)$ mengalami cemas berat, cemas sedang sebanyak 6 (26.1) serta sebanyak 8
(34.8\%) responden mengalami cemas ringan dan jumlah yang sama tidak mengalami kecemasan. Analisis hubungan status ekonomi dengan tingkat kecemasan ditunjukkan dengan hasil nilai $p$-value $0.016<0.05$ yang berarti bahwa terdapat hubungan yang signifikan pada status ekonomi dengan tingkat kecemasan responden. 


\section{PEMBAHASAN}

\section{Hubungan Tingat Pendidikan dengan Tingkat Kecemasan}

Pada tabel 1 di atas menunjukkan bahwa hasil analisis hubungan tingkat pendidikan dengan tingkat kecemasan adalah sebanyak 1 (4.8\%) responden dengan tingkat pendidikan SMA mengalami kecemasan berat pre operasi, diikuti oleh responden dengan tingkat pendidikan SD sebanyak 9 (32.1\%) mengalami kecemasan sedang, SMA sebanyak 6 (28.6\%) responden dan SMP 3 (37.5\%). Sedangkan pada tingkat kecemasan ringan sebanyak $14(50 \%)$ responden dengan tingkat pendidikan SD, $11(52.4 \%)$ pada tingkat pendidikan SMA dan 4(50\%) SMP. Pada responden yang tidak mengalami kecemasan yaitu sabanyak $5(17.9 \%)$ respnden dengan tingkat pendidikan SD, sebanyak 3 (14.3\%) dengan tingakt pendidikan SMA dan hanya 1 $(100 \%)$ pada tingkat pendidikan sarjana. Hasil $p$ value $0.643>0.05$ yang berarti bahwa tidak ada hubungan antara tingkat pendidikan dengan tingkat kecemasan.

Hasil penelitian ini sesuai dengan konsep yang menyatakan bahwa tingkat pendidikan individu berpengaruh terhadap kemampuan berfikir. Semakin tinggi tingkat pendidikan maka individu semakin mudah berfikir rasional dan menangkap informasi baru, sehingga semakin tinggi pendidikan seseorang semakin tinggi pula pengetahuan seseorang (Stuart G.W \& Laraia M.T, 2007).

Hasil penelitian menunjukkan tidak ada hubungan yang signifikan antara tingkat pendidikan dengan kecemasan. Responden dengan tingkat pendidikan sarjana tidak mengalami kecemasan sedangkan pada responden dengan tingkat pendidikan SD lebih banyak mengalami kecemasan dari ringan sampai sedang dengan jumlah total 23 responden, tetapi pada tingkat pendidikan yang lebih tinggi yaitu SMA terdapat 18 responden yang mengalami kecemasan, hal tersebut menunjukkan bahwa latar belakang pendidikan tidak mempengaruhi tingkat kecemasan seseorang dalam menghadapi operasi, karena tinggi rendahnya status pendidikan seseorang tidak dapat mempengaruhi persepsi yang dapat menimbulkan kecemasan. Penelitian yang dilakukan oleh Zamriati $\mathrm{W}$ et al, (2013) juga menyatakan bahwa tidak terdapat hubungan antara tingkat pendidikan dengan tingkat kecemasan pasien.

\section{Hubungan Usia dengan Tingkat kecemasan}

Berdasarakan tabel 2 didapatkan hasil analisis hubungan usia dengan tingkat kecemasan bahwa 1(3.3\%) responden mengalami kecemasan berat dengan usia dewasa, 7 (23.3\%) responden dengan tingkat kecemasan sedang, 13 (43.3\%) dengan cemas ringan dan $9(30.0 \%)$ tidak mengalami kecemasan. Sedangkan pada usia remaja yang mengalami kecemasan yaitu 11 (39.3\%) dengan cemas sedang, $16(57.1 \%)$ responden dengan cemas ringan dan yang tidak mengalami kecemasan hanya $1(3.6 \%)$. P-value menunjukkan $0.036<0.05$ yang berarti bahwa terdapat hubungan yang signifikan antara usia dengan tingkat kecemasan.

Hasil penelitian ini sejalan dengan penelitian yang dilakukan oleh Budiman. F et.al, (2015) yang menyatakan terdapat hubungan antara usia dengan tingkat kecemasan. Angka prevalensi kecemasan pada pasien pre operasi dalam kaegori tinggi yaitu sebanyak $83 \%$ responden dari usia remaja dan lansia mengalami kecemasan dari yang ringan sampai berat. Stuart G.W \& Laraia M.T (2007) menyatakan bahwa maturitas atau kematangan individu akan mempengaruhi kemampuan koping mekanisme seseorang sehingga individu yang lebih matur sukar mengalami kecemasan karena individu mempunyai kemampuan adaptasi yang lebih besar terhadap kecemasan dibandingkan usia yang belum matur. Terbukti pada penelitian didapatkan usia yang matur yaitu usia dewasa lebih prevalensi tingkat kecemasannya lebih sedikit dibandingkan dengan usia remaja. Hal ini membuktikan usia yang matur memiliki kemampuan koping yang cukup dalam mengatasi kecemasan.

\section{Hubungan Jenis Kelamin dengan Kecemasan}

Tabel 3 di atas menunjukkan hasil analisis hubungan jenis kelamin dengan kecemasan yaitu terdapat 1 (2.7\%) responden dengan jenis kelamin perempuan mengalami tingkat kecemasan berat, $16 \quad(43.2 \%)$ mengalami kecemasan sedang, 15 (40.5\%) mengalami kecemasan ringan dan $5 \quad(13.5 \%)$ tidak mengalami kecemasan. Hasil p-value $0.043<0.05$ yang berarti bahwa terdapat hubungan jenis kelamin dengan tingkat kecemasan. Sebuah penelitian yang dilakukan oleh Maryam dan Kurniawan A (2008) menyatakan bahwa faktor jenis kelamin secara signifikan dapat mempengaruhi tingkat kecemasan pasien, dalam penelitian tersebut disebutkan juga bahwa jenis kelamin perempuan lebih beresiko mengalami kecemasan dibandingkan dengan jenis kelamin laki-laki. 


\section{Hubungan Status Ekonomi dengan Kecemasan}

Berdasarkan analisis hubungan status ekonomi dengan kecemasan pada tabel 4 menunjukkan $1 \quad(4.3 \%)$ responden dengan penghasilan diatas UMR mengalami kecemasan berat, $6(26.1 \%)$ mengalami kecemasan sedang, 8 $(34.8 \%)$ responden mengalami cemas ringan dan $8 \quad(34.8 \%)$ tidak mengalami kecemasan. Sedangakan pada status ekonomi dengan penghasilan dibawah UMR didapatkan 12 (34.3\%) responden mengalami cemas sedang, 21 $(60.0 \%)$ responden mengalami cemas ringan dan hanya $2(5.7 \%)$ responden tidak mengalami kecemasan. $P$-value adalah $0.16<0.05$ yang berarti bahwa terdapat hubungan signifikan antara status ekonomi dengan kecemasan.

Penelitian yang dilakukan oleh Maryam dan Kurniawan A (2008) juga menjelaskan bahwa penghasilan yang digunakan sebagai indikator status ekonomi memiliki pengaruh terhadap tingkat kecemasan, hasil penelitian menunjukkan bahwa angka prevalensi penghasilan dibawah UMR mengalami kecemasan lebih banyak dibandingkan responden dengan penghasilan diatas UMR.

\section{SIMPULAN}

Berdasarkan hasil pembahasan maka dapat diambil beberapa kesimpulan sebagai berikut:

1. Distribusi frekuensi faktor tingkat pendidikan SD di wilayah kerja RS Mitra Husada Pringsewu lebih besar setelah tingkat pendidikan SMA yaitu sebanyak 28 (48\%) responden.

2. Distribusi frekuensi faktor usia dewasa responden di wilayah kerja RS Mitra Husada Pringsewu lebih besar dibandingkan usia remaja, yaitu sebanyak 30 (52\%)

3. Distribusi frekuensi faktor jenis kelamin perempuan responden diwilyah kerja RS Mitra Husada Pringsewu lebih besar dibandingkan dengan jenis kelamin laki-laki yaitu sebanyak $37(64 \%)$ responden.

4. Dsitribusi frekuensi faktor status ekonomi tingkat penghasilan di bawah UMR di wilayah kerja RS Mitra Husada Pringsewu lebih besar diabandingkan tingkat penghasilan diatas UMR yaitu sebanyak 35 $(60 \%)$

5. Tidak ada hubungan antara tingkat pendidikan dengan tingkat kecemasan (nilai $p$-value $=0.643>0.05$ )

6. Terdapat hubungan signifikan antara usia dengan tingkat kecemasan (nilai $p$ value $=0.036<0.05$ )

7. Terdapat hubungan signifikan antara jenis kelamin dengan tingkat kecemasan (nilai $p$ value $=0.043<0.05$ )

8. Terdapat hubungan signifikan antara tingkat penghasilan dengan kecemasan (nilai $p$ value $=0.016<0.05$ )

\section{SARAN}

1. Bagi RS Mitra Husada Pringsewu Tenaga kesehatan khususnya perawat perlu mengukur tingkat kecemasan pasien preoperative untuk dapat mengetahui keadaan umum dan TTV pasien sebagai persiapan operasi, serta menentukkan tindakan asuhan keperawatan segera jika terdapat pasien dengan tingkat kecemasan ringan sampai berat.

2. Bagi Institusi STIKes Muhammadiyah Pringsewu

Saran untuk institusi STIKes Muhammadiyah Pringsewu yaitu dapat dijadikan sebagai bahan mengajar hasil dari penelitian dan unit perpustakaan dapat menambah koleksi literatur terbaru terkait pre operasi.

3. Bagi Peneliti Selanjutnya

Untuk peneliti selanjutnya untuk dapat mengembangkan penelitian ini lebih lanjut dengan menganalisis lebih lanjut faktorfaktor lain yang dapat mempengaruhi tingkat kecemasan pasien.

4. Bagi Pasien Preoperative

Untuk dapat mengatasi kecemasan yang terdeteksi selama pre operasi, sehingga dapat memperlancar prosedur pre operasi.

\section{DAFTAR PUSTAKA}

Budiman, F., et.al. 2015. Faktor-faktor yang Berhubungan dengan Tingkat Kecemasan pada Pasien Infark Miokard Akut di Ruangan CVCU RSUP Prof. Dr. R. Kandou Manado. e- Journal Keperawatan

(e-Kp). Vol. 3 No. 3 Agustus 2015: Manado

Data Primer RS. Mitra Husada. 2016. Rekapitulasi Pasien Operasi. RS. Mitra Husada: Pringsewu. 
Fortinesh. 2007. Psychiatric Nursing Care Plane. California: Mosby Year.

Hawari, Dadan. 2013. Manajemen Stress, Cemas Dan Depresi. Jakarta: FKUI.

Kaplan and Sadock. 2010. Buku Ajar Psikiatri Klinis. Jakarta: EGC.

Maryam \& Kurniawan A. 2008. Faktor-faktor yang Berhubungan dengan Tingkat Kecemasan Orang Tua terkait Hospitalisasi Anak Usia Toddler di BRSD RAA Soewono Pati. FIKkes Jurnal Keperawatan, Vol. I No. 2 Maret 2008: pp. $38-56$.
Stuart, G.W., and Laraia, M.T. 2007. Principles and practice of psyhiatric nursing. $\left(8^{\text {th }}\right.$ ed.). St. Louis: Mosby Year B.

Sugiyono. 2007. Statistika untuk Penelitian. Bandung: CV Alfabeta.

Utama, Hendra. 2013. Buku Ajar Psikiatri. Ed 2. Jakarta: FKUI.

Zamriati. 2013. Faktor-faktor yang berhubungan dengan kecemasan ibu hamil menjelang persalinan di poli KIA PKM Tuminting. $E$ Journal Keperawatan (e-Kp), Volume I No. I Agustus 2013. Program Studi S1 Keperawatan. Fak. Kedokteran. Universitas Samratulangi Manado: Manado. 